\title{
ETS variant 1 regulates matrix metalloproteinase-7 transcription in LNCaP prostate cancer cells
}

\author{
SOOK SHIN, SANGPHIL OH, SEAYOON AN and RALF JANKNECHT \\ Department of Cell Biology, University of Oklahoma Health Sciences Center, Oklahoma City, OK 73104, USA
}

Received June 24, 2012; Accepted August 30, 2012

DOI: 10.3892/or.2012.2079

\begin{abstract}
Prostate cancer is characterized by the recurrent translocation of ETS transcription factors, including ETS variant 1 (ETV1) [also known as ETS-related 81 (ER81)]. Transgenic ETV1 mice develop prostatic intraepithelial neoplasia, yet the mechanisms by which ETV1 exerts its deleterious function remain largely unexplored. In this study, we demonstrated that ETV1 is capable of binding to the matrix metalloproteinase-7 (MMP-7) gene promoter both in vitro and in vivo. ETV1 stimulated the activity of the MMP-7 promoter, which was suppressed upon mutation of two ETV1 binding sites located within 200 base pairs upstream of the MMP-7 transcription start site. ETV1 overexpression in human LNCaP prostate cancer cells induced endogenous MMP-7 gene transcription, whereas ETV1 downregulation had the opposite effect. While MMP-7 overexpression did not influence LNCaP cell proliferation, it increased cell migration, which may be important during later stages of tumorigenesis. Finally, MMP-7 mRNA was significantly overexpressed in human prostate tumors compared to normal tissue. Together, these results showed that MMP-7 is a bona fide ETV1 target gene, implicating that MMP-7 upregulation is partially responsible for the oncogenic effects of ETV1 in the prostate.
\end{abstract}

\section{Introduction}

ETS variant 1 (ETV1) [also known as ETS-related 81 (ER81)] is a transcription factor that belongs to a large family of proteins characterized by a 25 amino acid-long ETS DNA-binding domain (1-5). ETV1 expression is developmentally and tissuespecifically controlled (1,6-9), suggesting that ETV1 plays an important ontogenetic role. ETV1-knockout mice display limb ataxia, abnormal flexor-extensor posturing of their limbs and

Correspondence to: Dr Ralf Janknecht, University of Oklahoma Health Sciences Center, 975 NE 10th Street, BRC-1464, Oklahoma City, OK 73104, USA

E-mail: ralf-janknecht@ouhsc.edu

Key words: cell migration, ETS transcription factor, ETS variant 1, gene transcription, matrix metalloproteinase-7, prostate cancer an anomalous development of sensory neurons and muscle spindles. Due to these defects, ETV1-knockout mice die 3-5 weeks after birth $(10,11)$.

The transcriptional activity of ETV1 is regulated by posttranslational modification. Central to this is the activation of the mitogen-activated protein (MAP) kinase pathway (12). MAP kinases phosphorylate ETV1 on two serine and two threonine residues and an additional two serine residues are phosphorylated by MAPKAP kinases that are activated by MAP kinases. As a consequence of its phosphorylation, ETV1 transcriptional activity becomes greatly enhanced (13-16). In addition to phosphorylation, ETV1 may be acetylated on two lysine residues, which is due to $\mathrm{p} 300$ (or its paralog CBP) and PCAF, acetyltransferases that bind to ETV1 and are known coactivators (17-20). Importantly, MAP kinases appear to stimulate the acetyltransferase activity of p300 and the resultant acetylation of ETV1 also increases its transactivation potential (18). Moreover, ETV1 interacts with steroid receptor coactivators that are activated by MAP kinase phosphorylation (21-23). Thus, ETV1 may be an important downstream effector of a plethora of signals that funnel through the MAP kinase pathway.

The first indication that ETV1 is involved in tumorigenesis emerged from the analysis of Ewing tumors, which arise as a consequence of chromosomal translocations affecting the EWS gene $(24,25)$. In particular, the $\mathrm{N}$-terminus of EWS, which represents a potent transactivation domain (26), was found to be translocated onto the C-terminus of ETV1, including its DNA-binding domain (6). This results in an oncogenic EWS-ETV1 fusion protein that is constitutively activated and not dependent on MAP kinase stimulation. However, more recently other chromosomal translocations involving ETV1 were observed in prostate tumors, leading to the overexpression of ETV1 (27-31). Mimicking this ETV1 overexpression in transgenic mouse models induced the development of prostatic intraepithelial neoplasia, the precursor of prostate carcinomas, indicating that ETV1 overexpression is an underlying cause of prostate cancer initiation $(28,32)$. Lastly, copy number amplification of the ETV1 gene was found in $~ 40 \%$ of melanomas (33), suggesting that ETV1 overexpression also contributes to skin cancer. Consistently, downregulation of ETV1 in melanoma cells suppressed proliferation and anchorageindependent growth, whereas the overexpression of ETV1 led to the transformation of immortalized melanocytes. However, this transforming activity of ETV1 was dependent on the coexpression of molecules that induce MAP kinase activity, 
$\mathrm{N}$-Ras or B-Raf, suggesting that post-translational modification of ETV1 is required for its transforming activity (33).

ETV1 ultimately affects tumorigenesis by dysregulating gene transcription. Thus, the identification of ETV1 target genes merits further attention, since this will increase our understanding of prostate tumorigenesis and point out potential avenues of therapeutic intervention. Currently, only a few validated ETV1 target genes are known. This includes human telomerase reverse transcriptase (34), which is upregulated in the vast majority of all tumors, where it is responsible for maintaining telomere length that is crucial for unlimited proliferation $(35,36)$. Another ETV1 target gene is HER2/ Neu (37), which is overexpressed in $\sim 10 \%$ of all prostate tumors. However, HER2/Neu overexpression increases with the progression of the disease and has been observed in excess of $50 \%$ of all androgen depletion independent prostate tumors in a number of studies (38-40). Furthermore, the transforming growth factor- $\beta$ (TGF- $\beta$ ) signaling pathway inhibitor Smad7 is an ETV1 target gene (41). TGF- $\beta$ signaling is a prominent tumor-suppressing pathway that is intracellularly relayed via the receptor-regulated R-Smad proteins (42). Smad7 is different from the R-Smads and antagonizes them by preventing their phosphorylation by TGF- $\beta$ type I receptors and by downregulating TGF- $\beta$ receptors through the recruitment of ubiquitin ligases. Accordingly, Smad7 overexpression may be linked to tumor formation and, indeed, has been observed in several types of cancers (43). In this study, we investigated whether matrix metalloproteinase-7 (MMP-7) is a bona fide ETV1 target gene in prostate cancer cells.

\section{Materials and methods}

Electrophoretic mobility shift assays. The following oligonucleotide pairs were hybridized to generate double-stranded MMP-7 promoter oligonucleotides: -55 ETS, 5'-ATGAGTCACCTATT TCCACATTCGAGGCTG-3' and 5'-CTCAGCCTCGAATGTG GAAATAGGTGACTC-3'; -144 ETS, 5'-ATAACGATGTAATA CTTCCTCGTTTT-3' and 5'-ACTAAAACGAGGAAGTATTA CATCGTT-3'; -168 ETS, 5'-CATTGTGTGCTTCCTGCCAAT AACG-3' and 5'-CATCGTTATTGGCAGGAAGCACACA-3'.

Double-stranded oligonucleotides were labeled with ${ }^{32} \mathrm{P}$-dATP using Klenow DNA polymerase (44). Binding reactions were performed in $10 \mu \mathrm{l}$ of $20 \mathrm{mM}$ HEPES pH 7.4, $25 \mathrm{mM} \mathrm{NaCl}, 12 \%$ glycerol, $0.01 \%$ Tween 20, $2 \mathrm{mM}$ DTT, $0.1 \mu \mathrm{g} / \mu \mathrm{l}$ bovine serum albumin and $0.05 \mu \mathrm{g} / \mu \mathrm{l}$ poly $(\mathrm{dIdC})^{*}(\mathrm{dIdC})$. Where indicated, bacterially expressed and purified ETV1 encompassing amino acids 249-477 (13), $0.5 \mu 1$ anti-ETV1 antibody (C-20; Santa Cruz Biotechnology, Inc.), unlabeled double-stranded E74 or mE74 oligonucleotide (45) were added together with ${ }^{32} \mathrm{P}$-labeled oligonucleotide to the reaction mix. Reactions were allowed to proceed for $20 \mathrm{~min}$ at $4^{\circ} \mathrm{C}$. Resulting DNA-protein complexes were then separated on native polyacrylamide gels in a cold room and visualized by autoradiography of the dried gels.

Chromatin immunoprecipitation (ChIP) assays. Human LNCaP prostate cancer cells were grown in $10 \%$ charcoalstripped serum with or without $1 \mathrm{nM}$ mibolerone and ChIP assays were performed as described (46). To amplify a 270-bp fragment of the human MMP-7 promoter, a nested
PCR was performed according to the following program: $98^{\circ} \mathrm{C}$ for $2 \mathrm{~min} ; 6$ cycles of $98^{\circ} \mathrm{C}$ for $30 \mathrm{sec}, 64^{\circ} \mathrm{C}$ for $30 \mathrm{sec}$ $\left(-1^{\circ} \mathrm{C} /\right.$ cycle), $72^{\circ} \mathrm{C}$ for $25 \mathrm{sec} ; 20$ cycles (first PCR) or 19 cycles (second PCR) of $98^{\circ} \mathrm{C}$ for $30 \mathrm{sec}, 58^{\circ} \mathrm{C}$ for $30 \mathrm{sec}, 72^{\circ} \mathrm{C}$ for $25 \mathrm{sec}(+1 \mathrm{sec} /$ cycle $)$ and $4 \mathrm{~min}$ at $72^{\circ} \mathrm{C}$. For the first PCR, MMP-7pro-forl (5'-GTCCTGAATGATACCTATGAGAGC-3'; -290 to -267 of the MMP-7 promoter) and MMP-7pro-rev1 (5'-CCAGAGACAATTGTTCTTGGACC-3'; +38 to +16 of the MMP-7 promoter) were utilized as primers, and MMP-7pro-for2 (5'-CATGGAGTCAATTTATGCAGCAGAC-3'; -232 to -208 of the MMP-7 promoter) and MMP-7pro-rev1 for the second PCR. For amplification of a 338-bp fragment of the human MDM2 promoter, the same PCR program was employed (32 repeats at a $58^{\circ} \mathrm{C}$ annealing temperature) with previously described primers (47). Amplified promoter DNA fragments were visualized by ethidium bromide staining on agarose gels (48).

Luciferase assays. The human MMP-7 promoter (-301 to +52) was amplified by PCR from genomic DNA and cloned into the luciferase reporter construct, pGL2-Basic (Promega). Site-directed mutagenesis was performed to change the ETS core sequence at -55 and/or -168 from GGAA to CCAA. All constructs were verified by DNA sequencing. Human embryonic kidney $293 \mathrm{~T}$ cells were grown in polylysine-coated 12-well plates (49) and transiently transfected by the calcium phosphate coprecipitation method (50). MMP-7 (500 ng) reporter gene construct, $50 \mathrm{ng} \mathrm{CMV}-\mathrm{lacZ}, 1 \mu \mathrm{g}$ pBluescript $\mathrm{KS}^{+}$, and indicated amounts of vector or ETV1 expression construct were employed. In case of rabbit kidney RK13 cells, $500 \mathrm{ng}$ MMP-7 reporter gene construct, $1.2 \mu \mathrm{g}$ pBluescript $\mathrm{KS}^{+}$, $30 \mathrm{ng}$ pEV3S vector or ETV1 expression construct, and $100 \mathrm{ng}$ HER2/Neu-V664E plasmid (51) were used. Thirty-six hours after transfection, cells were lysed (52) and the cleared lysate was employed to measure luciferase activity as described (53).

Retroviral infection. To downregulate human ETV1, shRNA targeting the sequence 5'-UUCGATGGAGACAUCAAAC-3' was cloned into pSIREN-RetroQ (Clontech). To overexpress ETV1, murine ETV1 cDNA was cloned into pQCXIP (Clontech). Retrovirus was then produced in 293T cells according to standard procedures (54) and employed to infect LNCaP cells two times within $24 \mathrm{~h}$, which were then grown for an additional $72 \mathrm{~h}$ (55). Overexpression or downregulation of ETV1 was ascertained by standard western blotting procedures of cell extracts (56) and utilizing secondary antibodies coupled to horseradish peroxidase and employment of enhanced chemiluminescence (57). Similarly, retrovirus expressing MMP-7 shRNA (shRNA\#1, 5'-GGGAACAGGCUCAGGACUA-3'; shRNA\#4, 5'-CCUACAGGAUCGUAUCAUA-3') or human MMP-7 cDNA was generated and utilized.

$R T$-PCR. Total RNA was extracted from LNCaP cells employing TRIzol (Invitrogen) and 50 ng RNA was used for amplification with the Access Quick RT-PCR kit (Promega) (58). The following PCR program was utilized: $48^{\circ} \mathrm{C}$ for $45 \mathrm{~min} ; 96^{\circ} \mathrm{C}$ for $2 \mathrm{~min}$; 25-35 repeats of $95^{\circ} \mathrm{C}$ for $30 \mathrm{sec}, 58^{\circ} \mathrm{C}$ for $45 \mathrm{sec}$ and $68^{\circ} \mathrm{C}$ for $45 \mathrm{sec}$; final extension for $5 \mathrm{~min}$ at $68^{\circ} \mathrm{C}$. The MMP-7 primers used were 5'-TGTGGAGTGCCAGATGTTGCAG-3' and 5'-CTAAATGGAGTGGAGGAACAGTGC-3', resulting in a 642 bp cDNA fragment. GAPDH mRNA was assayed as 
A

\begin{tabular}{|c|c|c|}
\hline-301 & GTACCATAATGTCCTGAATGATACCTATGAGAGCAGTCATTTGACTTTGGCAAAAAAAT & -242 \\
\hline-241 & AAAAATCCTTTGAAAGACAA & -182 \\
\hline-181 & ATACATTGTGTGQTTCOTGCCAATAACGATGTAATA TTCCICGTTTTAGTTAATGAAAA & -122 \\
\hline-121 & AAAGTTCTGTAGACTCTAAAAA & -62 \\
\hline-61 & ITCGAGGCTGAGAAGCTATATAAATTTCTGCAGTCACTAGCAGAAAA & -2 \\
\hline-1 & ГAGGTCCAAGAACAATTGTCTCTG & +52 \\
\hline
\end{tabular}

B

\section{ETS Binding Sequences}
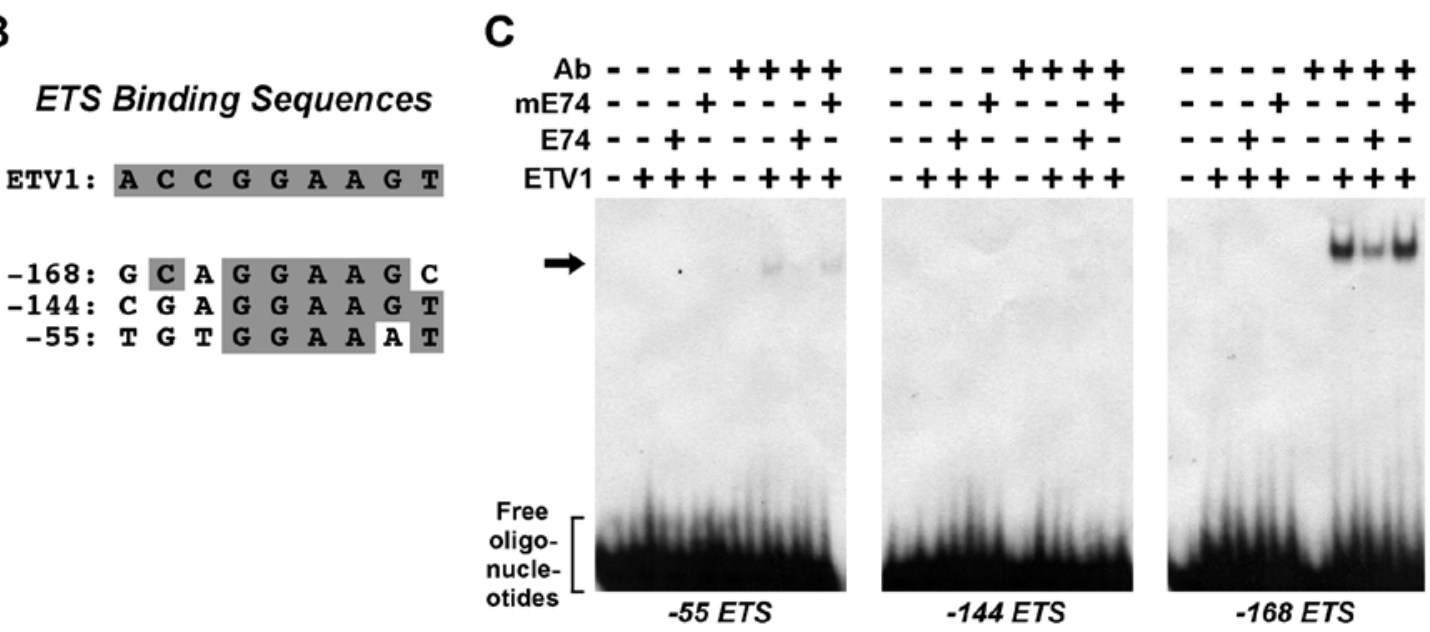

Figure 1. Direct binding of ETV1 to the MMP-7 promoter. (A) DNA sequence of the human MMP-7 promoter from -301 to +52. The 5'-GGAA-3' (5'-TTCC-3' in reverse) core of ETS binding sites at -55, -144 and -168 is shown in boxes. (B) Alignment of the indicated MMP-7 ETS sites (complementary strand) to the consensus ETV1 binding site. (C) Gel electrophoretic mobility shift assays with indicated ETS sites. Recombinant ETV1, unlabeled oligonucleotides (E74 or mE74) and ETV1 antibody (Ab) were incubated with ${ }^{32} \mathrm{P}$-labeled oligonucleotides and then separated on native gels. Shown are respective autoradiograms. Arrow indicates binding of ETV1 to ${ }^{32} \mathrm{P}$-labeled DNA.

described (59). For determining MMP-7 mRNA levels in cells expressing MMP-7 shRNA, a two-step reaction was performed. First, RT-PCR was carried out with primers MMP-7-b-for (5'-AGATGTGGAG TGCCAGATGT-3') and MMP-7-a-rev (5'-CCAATGAATGAA TGAATGGATG-3') using the PCR program: $48^{\circ} \mathrm{C}$ for $45 \mathrm{~min} ; 96^{\circ} \mathrm{C}$ for $2 \mathrm{~min} ; 20$ repeats of $95^{\circ} \mathrm{C}$ for $30 \mathrm{sec}, 56^{\circ} \mathrm{C}$ for $30 \mathrm{sec}$, and $68^{\circ} \mathrm{C}$ for $30 \mathrm{sec}$; final extension for $4 \mathrm{~min}$ at $68^{\circ} \mathrm{C}$. Second, PCR was carried out with MMP-7b-for and MMP-7-b-rev (5'-TAGAC TGCTACCATCCGTCC-3') primers employing iProof high-fidelity DNA polymerase (Bio$\mathrm{Rad}$ ) with the PCR program: $98^{\circ} \mathrm{C}$ for $2 \mathrm{~min} ; 30$ repeats of $98^{\circ} \mathrm{C}$ for $30 \mathrm{sec}, 56^{\circ} \mathrm{C}$ for $30 \mathrm{sec}$, and $72^{\circ} \mathrm{C}$ for $30 \mathrm{sec}$; final extension for 4 min at $72^{\circ} \mathrm{C}$, resulting in a 357-bp cDNA product. Similarly, ETV1 expression was analyzed using hETV1-RT-for (5'-TCCCTCCATCGCAGT CCATACCAG-3') and hETV1-RTrev (5'-GTGGCAGCTAGG CACTTCTGAGTC-3') primers in the RT-PCR reaction (15 repeats) followed by 20 cycles of nested PCR with hETV1-RT-for and hETV1-RT-rev-new (5'-CATATGCAAAATCTCTGG GTTCCTG-3') primers, generating a 291-bp cDNA product. All resultant cDNA fragments were electrophoresed on $1.5 \%$ agarose gels and stained with ethidium bromide (60).

Proliferation assay. LNCaP cells were infected with the indicated retrovirus and selected for at least four days with $1 \mu \mathrm{g} / \mathrm{ml}$ puromycin. Thereafter, cells were seeded into 96-wells (61) and one day later (designated as Day 0) for the first time were analyzed with an MTT (3-[4,5-dimethylthiazol-2-yl]-2,5-diphenyltetrazolium bromide) assay (Trevigen) according to the manufacturer's instructions. Further measurements were taken 2,3 or 5 days thereafter.

Migration assay. Puromycin-selected LNCaP cells $\left(2 \times 10^{5}\right)$ (as mentioned above) were seeded into a 24-well format cell culture insert with an $8 \mu \mathrm{m}$ pore size (353097; Becton-Dickinson) in serum-free media. Migration towards media containing $10 \%$ fetal calf serum was measured after $24 \mathrm{~h}$. Migrated cells on the bottom of the membrane were visualized using the Hemacolor staining kit (EMD Millipore) and then counted.

\section{Results}

Binding of the ETS transcription factor ETVI to the MMP-7 gene promoter. Previous reports indicate that the MMP-7 gene is transcriptionally activated by a number of ETS transcription factors $(62,63)$. Thus, we reasoned that MMP-7 may be a new ETV1 target gene in prostate cancer cells. To prove this, we first assessed whether ETV1 directly binds to the MMP-7 gene promoter. We analyzed the human MMP-7 promoter for the presence of potential ETV1-binding sites, which have the consensus sequence 5'-ACCGGAAGT-3'; the GGAA core is the most important determinant of the DNA-binding affinity (64). Three such ETS sites are present in the MMP-7 promoter (Fig. 1A), which match to a varying degree to the ETV1consensus binding sequence (Fig. 1B).

To study which of these three ETS sites would be bound by ETV1, we performed electrophoretic mobility shift assays. When ETV1 was incubated alone with respective radioactively 


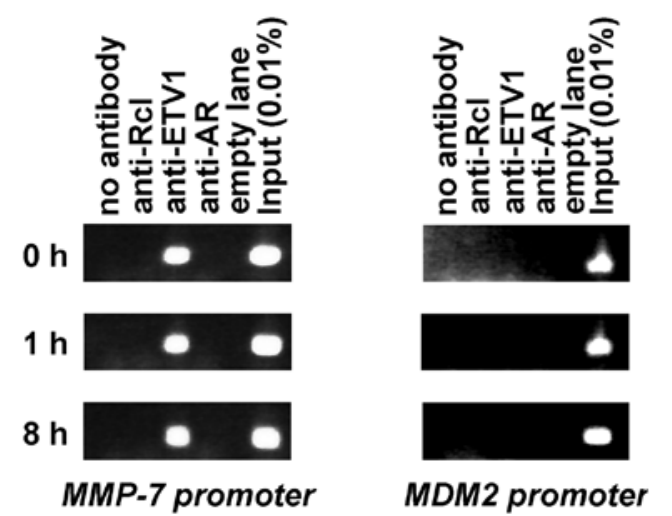

Figure 2. Recruitment of ETV1 to the MMP-7 promoter in vivo. LNCaP cells were incubated in androgen-depleted media and then induced for 0,1 or $8 \mathrm{~h}$ with a synthetic androgen. Immunoprecipitations were performed with indicated antibodies and precipitated DNA was amplified with MMP-7 (left panels) or MDM2 (right panels) specific primers.

labeled oligonucleotides, ETV1 binding was not observed (Fig. 1C). However, previous studies showed that ETV1 DNA binding is inhibited in vitro by its $\mathrm{C}$-terminus, but an additional antibody recognizing its C-terminus alleviates this intramolecular inhibition $(37,41)$. This intramolecular inhibition appears to be especially important at the ETV1-binding sites that do not match the consensus binding sequence, as is the case for all three ETS sites within the MMP-7 promoter (Fig. 1B). Thus, we also included an antibody recognizing the ETV1 C-terminus in the binding reaction and observed strong binding of ETV1 to the -168 ETS site, weak binding to the -55 ETS site, while no binding to the -144 ETS site was observed (Fig. 1C). To examine binding specificity, we also performed competition experiments with the E74 site that completely matches the ETV1-binding site consensus and readily interacts with ETV1 and other ETS proteins $(12,65)$. Unlabeled E74 oligonucleotide efficiently reduced ETV1 binding to the radioactively labeled -168 and -55 ETS sites, whereas a mutated E74 oligonucleotide did not (Fig. 1C). Together, these data demonstrate that ETV1 is capable of binding to the MMP-7 promoter at two sites in vitro.

To examine whether ETV1 also binds in vivo to the MMP-7 promoter, we performed ChIP assays in LNCaP cells. Since ETV1 binding was previously shown to cooperate with the androgen receptor (AR) in binding to the prostate-specific antigen enhancer (32), we also investigated the influence of androgen stimulation on MMP-7 promoter interaction. We deprived LNCaP cells of androgen and then induced them for 1 or $8 \mathrm{~h}$ with the synthetic androgen, mibolerone. Utilizing anti-ETV1 antibodies, the MMP-7 promoter was immunoprecipitated before and after mibolerone stimulation (Fig. 2, left panels), showing that ETV1 may bind to the MMP-7 promoter in cells and that this binding is independent of androgen. Accordingly, anti-AR antibodies did not immunoprecipitate the MMP-7 promoter, nor did the control anti-Rcl antibodies. Furthermore, ETV1 did not interact with the MDM2 promoter (Fig. 2, right panels), attesting to the specificity of our ChIP assay. Thus, ETV1 binds to the MMP-7 promoter in vivo.

Activation of the MMP-7 promoter by ETVI. To demonstrate that ETV1 not only binds, but also stimulates the MMP-7 gene
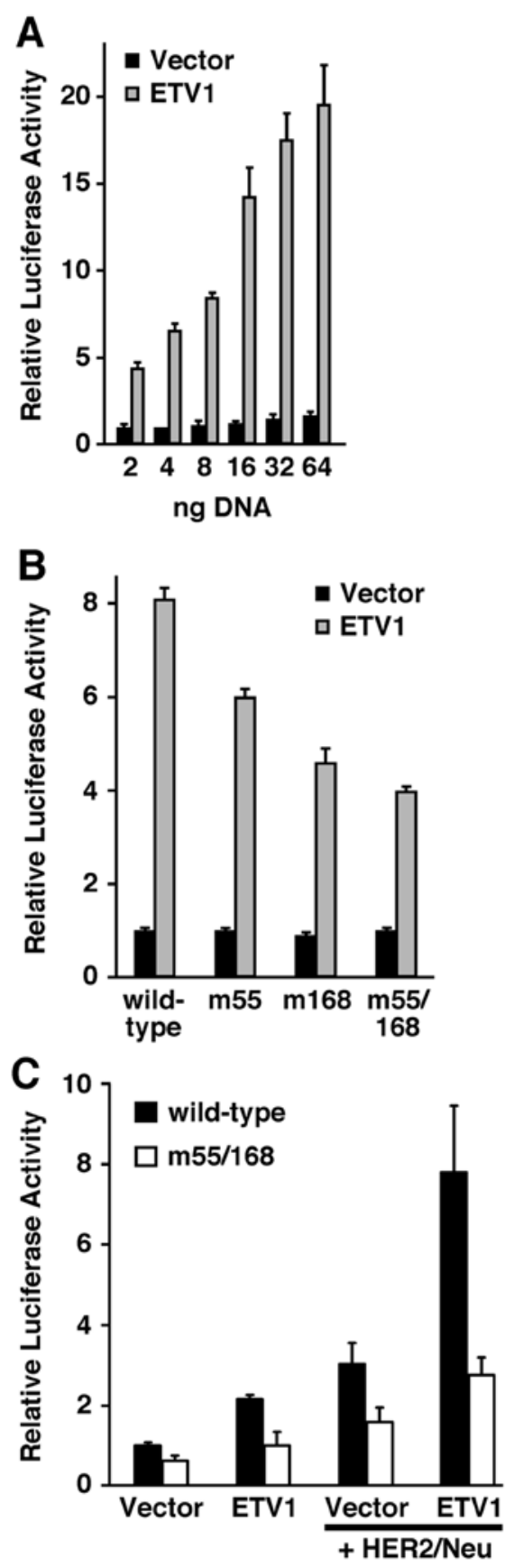

Figure 3. Activation of the MMP-7 promoter by ETV1. (A) The MMP-7 $(-301 /+52)$ luciferase reporter plasmid was transfected into $293 \mathrm{~T}$ cells. In addition, various amounts of empty vector or ETV1 expression plasmid were cotransfected. Resultant luciferase activities are depicted. (B) Wild-type MMP-7 luciferase reporter construct or mutation at the -55 ETS (m55), -168 ETS (m168) or at both ETS sites (m55/168) was cotransfected with $8 \mathrm{ng}$ of empty vector or ETV1 expression plasmid into 293T cells. (C) ETV1 and/or HER2/Neu were coexpressed in RK13 cells as indicated. The impact on the cotransfected wildtype or m55/168 MMP-7 luciferase reporter gene was measured.

promoter, we cloned respective human DNA into a luciferase reporter plasmid. This reporter gene was transfected with increasing amounts of an empty vector or ETV1 expression plasmid into 293T cells. Whereas the empty vector barely affected the MMP-7 luciferase reporter gene activity, ETV1 stimulated the MMP-7 promoter in a dose-dependent manner up to $\sim 20$-fold (Fig. 3A). 
A

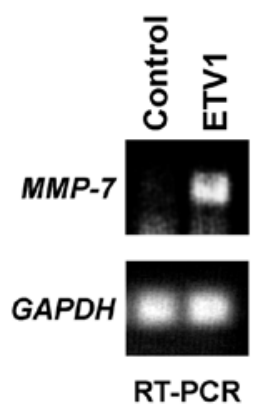

B

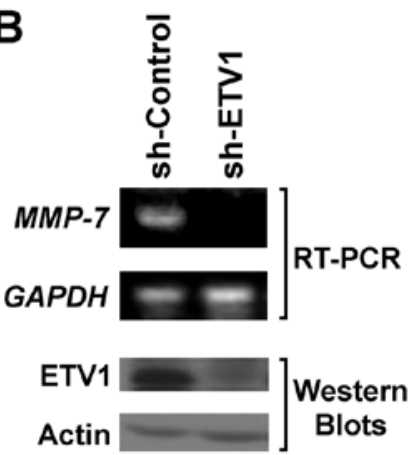

Figure 4. ETV1 stimulates endogenous MMP-7 transcription. (A) LNCaP cells were infected with a retrovirus expressing ETV1 or the control retrovirus. RT-PCR was performed to detect MMP-7 and GAPDH levels, as the control. (B) LNCaP cells were infected with retrovirus expressing ETV1 shRNA or the control shRNA. Levels of MMP-7 and GAPDH mRNA were measured by RT-PCR (top panels), whereas ETV1 and actin protein levels were determined by western blotting (bottom panels).
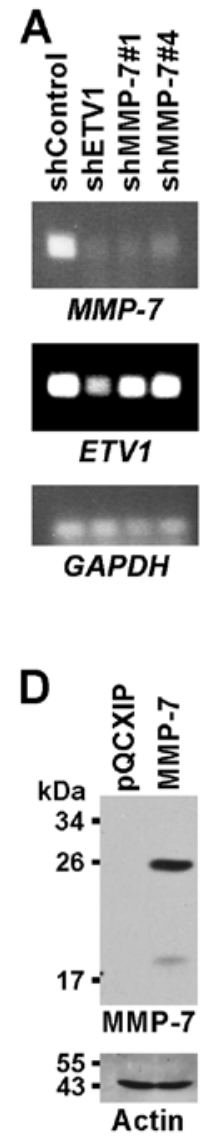

B

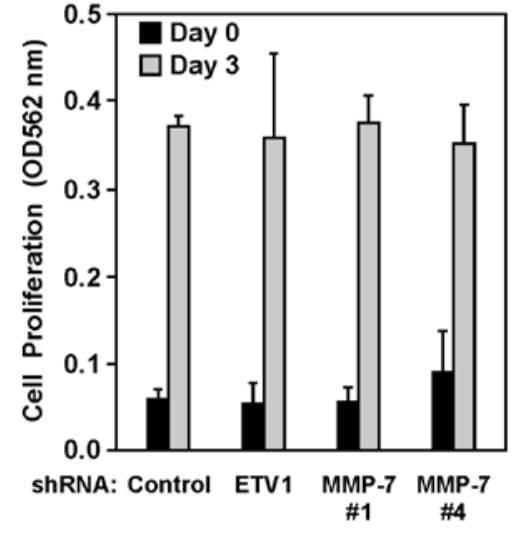

E

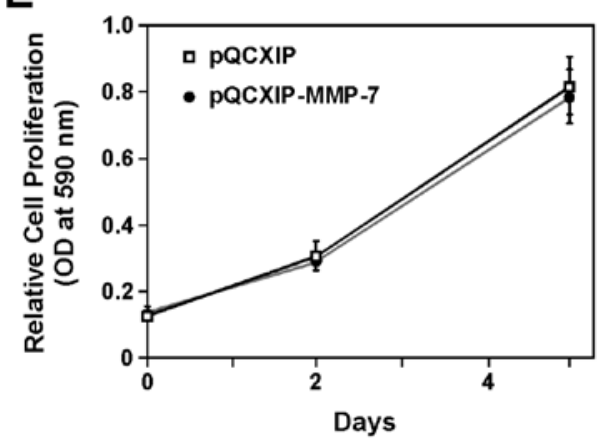

C

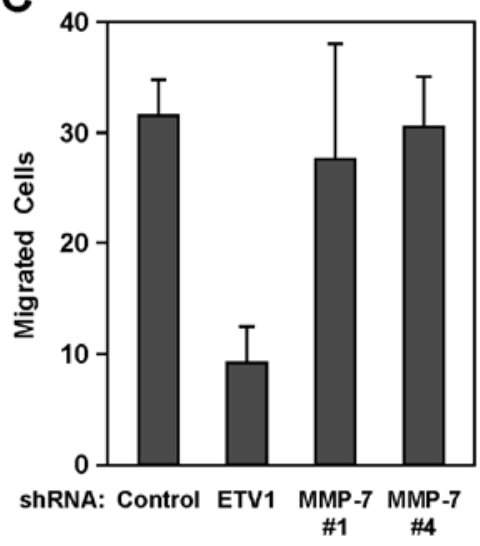

$\mathbf{F}$

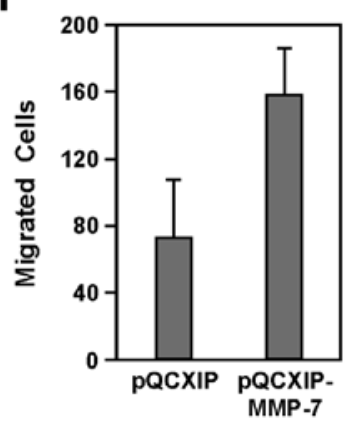

Figure 5. Role of MMP-7 in LNCaP cell migration. (A) RT-PCR of LNCaP cells expressing ETV1 or MMP-7 shRNA (\#1 and \#4). (B) Proliferation and (C) migration of shRNA-expressing LNCaP cells. (D) Western blotting showing the expression of MMP-7 protein in LNCaP cells infected with MMP-7 or the control (pQCXIP) retrovirus. Actin levels were determined as a control. (E) Proliferation of the control LNCaP cells (infected with pQCXIP retrovirus) or LNCaP cells overexpressing MMP-7. (F) Migration of LNCaP cells expressing the vector control (pQCXIP) or MMP-7. Statistical significance (P=0.0248) was determined with an unpaired, two-tailed t-test.

Next, we tested how mutation of the ETV1-binding sites identified above would affect MMP-7 promoter activity. In the absence of ETV1, mutation of the -55 ETS, -168 ETS site or of both sites had no impact on MMP-7 reporter gene activity in 293T cells (Fig. 3B). However, in the presence of ETV1, mutation of ETS sites at -55 and -168, individually or combined, reduced MMP-7 promoter activity. As expected, mutation of the -55 ETS site had a weaker effect compared to the mutation of the -168 ETS site, while the strongest effect was observed upon mutation of both ETS sites, reducing ETV1-induced MMP-7 promoter activity by half (Fig. 3B). The fact that the MMP-7 promoter remained inducible by ETV1 upon mutation of both ETV1-binding sites may be due to the indirect effects of ETV1; such as the induction of another gene encoding a transcription factor that is also capable of stimulating the MMP-7 promoter. 


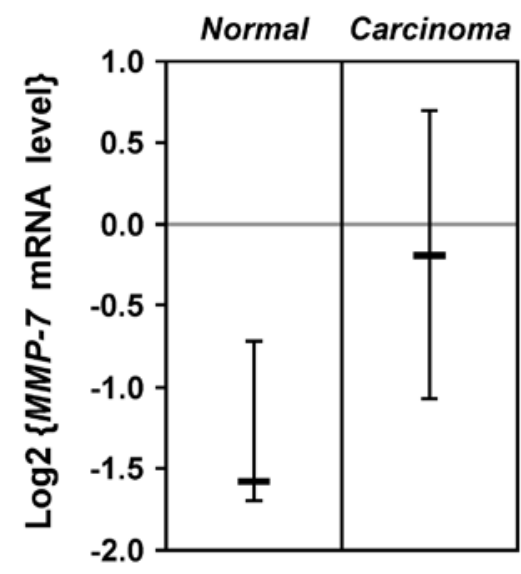

Figure 6. Overexpression of MMP-7 in human prostate tumors. Twenty-three normal and 65 cancerous prostate tissues were compared with the Oncomine Web Tool (www.oncomine.org). Shown is the median (with $25-75 \%$ range) of $\log$ 2-transformed MMP-7 mRNA levels. $\mathrm{P}=0.007$ as determined by Student's t-test.

We also assessed the ability of ETV1 to induce the MMP-7 promoter in another cell line, RK13. Again, we observed that ETV1 induced MMP-7 promoter activity, and mutation of the ETS sites at -55 and -168 severely compromised this activation (Fig. 3C). In contrast to the 293T cells, mutation of the -55 and -168 ETS sites even suppressed MMP-7 promoter activity in the absence of ETV1, which was probably due to the fact that RK13 cells harbor endogenous ETV1. We also demonstrated how the induction of ETV1 transcriptional activity by HER $2 / \mathrm{Neu}$, a receptor tyrosine kinase that stimulates the MAP kinase pathway and thus the ETV1 transactivation potential $(12,13,66)$, would affect MMP-7 promoter activity. In the absence of ectopic ETV1, HER2/Neu stimulated the MMP-7 promoter, possibly due to endogenous ETV1 in the RK13 cells (Fig. 3C). Moreover, HER2/Neu cooperated with ectopic ETV1 to stimulate MMP-7 luciferase reporter activity, which was drastically reduced upon mutation of the -55 and -168 ETS sites (Fig. 3C). Altogether, our promoter studies strongly suggest that ETV1 activates the MMP-7 promoter through the -55 and -168 ETS sites.

Endogenous MMP-7 transcription is activated by ETV1. To corroborate that ETV1 also stimulates the endogenous MMP-7 promoter, we infected human LNCaP prostate cancer cells with a retrovirus overexpressing ETV1. ETV1 overexpression led to strongly enhanced MMP-7 mRNA levels in LNCaP cells as determined by RT-PCR (Fig. 4A). By utilizing a limited number of PCR amplifications we were unable to detect MMP-7 mRNA in the absence of ectopic ETV1.

Conversely, we expressed shRNA targeting ETV1 in LNCaP cells. By utilizing more cycles of amplification than mentioned above to detect endogenous MMP-7 expression by RT-PCR, we observed that the downregulation of ETV1 resulted in a robust decrease in MMP-7 mRNA levels compared to cells expressing a control shRNA (Fig. 4B, top panels). Western blotting confirmed that ETV1 protein was reduced by ETV1 shRNA (Fig. 4B, bottom panels). Together, these results indicate that MMP-7 transcription is activated by ETV1 in LNCaP prostate cancer cells.
Role of MMP-7 in LNCaP cells. To define the importance of MMP-7 for the biology of LNCaP cells, we first elected to downregulate MMP-7 with shRNAs. Similar to ETV1 shRNA, both of the MMP-7 shRNAs employed strongly reduced MMP-7 mRNA levels in LNCaP cells (Fig. 5A). Downregulation of MMP-7 or ETV1 had no impact on LNCaP cell proliferation (Fig. 5B), and MMP-7 shRNA also did not affect the ability of LNCaP cells to migrate (Fig. 5C). In contrast, downregulation of ETV1 reduced LNCaP cell migration (Fig. 5C), which is similar to the reported reduction of $\mathrm{LNCaP}$ cell invasion caused by ETV1 siRNA $(28,67)$.

We next infected LNCaP cells with an MMP-7-expressing retrovirus. Although we were unable to detect MMP-7 protein in the control cells, robust MMP-7 expression was observed upon infection with the MMP-7 retrovirus (Fig. 5D). A change in the cell proliferation was not noted upon MMP-7 overexpression (Fig. 5E), but LNCaP cell migration was significantly enhanced (Fig. 5F). These data suggest that ETV1-mediated MMP-7 upregulation may particularly contribute to tumor metastasis, which entails cancer cell migration.

Overexpression of MMP-7 in human prostate tumors. Recurrent translocation of the ETV1 gene and the resultant overexpression of the ETV1 protein contributes to prostate cancer (68). Therefore, one would predict that MMP-7, as a target gene of ETV1, is upregulated in prostate tumors. To prove this, we analyzed published microarray data (69). The comparison of 23 normal prostate tissues to 65 prostate carcinomas revealed that MMP-7 mRNA is significantly overexpressed in prostate tumors (Fig. 6). Thus, MMP-7 may indeed be a physiologically relevant target gene of ETV1 during prostate cancer formation.

\section{Discussion}

In this study, we demonstrated that MMP-7 is a bona fide target gene of ETV1 in LNCaP prostate cancer cells based on the following results. First, ETV1 binds to two ETS sites in the MMP-7 promoter in vitro and also interacts with the MMP-7 promoter in LNCaP cells in vivo. Second, ETV1 stimulates an MMP-7 luciferase reporter construct and mutation of two ETV1 binding sites diminished this stimulation. Third, the overexpression or downregulation of ETV1 in LNCaP cells activated or repressed, respectively, the endogenous MMP-7 gene transcription.

Furthermore, our results revealed that MMP-7 gene transcription is significantly upregulated in human prostate tumors. These data complement previous studies demonstrating the presence of MMP-7 mRNA in Northern blot analyses of human prostate tumor samples $(70,71)$ and analyses in rat models of prostate cancer showing that MMP-7 is upregulated during carcinogenesis $(72,73)$. Moreover, it was recently found that serum levels of MMP-7 are increased in metastatic prostate cancer patients, but a difference between the control patients and those with localized disease was not observed (74). Accordingly, high MMP-7 serum levels were correlated with poor prognosis, strongly indicating that MMP-7 upregulation contributes to the development of aggressive prostate cancer. This would be similar to other types of cancer, for 
which respective recombinant mouse models prove a causal relationship between MMP-7 and tumorigenesis. For instance, knock out of MMP-7 counteracted colon or pancreatic cancer formation, while MMP-7 overexpression was shown to accelerate breast tumorigenesis induced by HER2/Neu (75-77). Notably, our results revealed that HER2/Neu targets ETV1 to stimulate MMP-7 transcription. Thus, HER2/Neu, which is overexpressed in the majority of prostate tumors (38-40), may synergize with ETV1 overexpression to induce MMP-7 gene transcription in prostate cancer.

ETV1 overexpression has been shown to increase the migration of PNT2C2 and RWPE-1 prostate cells $(30,78)$, whereas ETV1 downregulation decreased LNCaP cell invasion $(28,67)$. Similarly, we observed that ETV1 shRNA reduced LNCaP cell migration, but this was not caused by decreased MMP-7 transcription, since MMP-7 shRNA itself did not have an impact on LNCaP cell migration. This may be due to the fact that ETV1 not only affects MMP-7 expression, but potentially the transcription of several other proteinases involved in cell migration, including the ETV1 target gene, MMP-1 (13). Thus, it is conceivable that MMP-7 downregulation alone will not be sufficient to reduce cell migration. Regardless, the fact that MMP-7 overexpression increased LNCaP cell migration (in the current study) and DU-145 prostate cancer cell invasion (79) indicates the physiological relevance of MMP-7 in prostate cancer. Since MMP-7 antibodies were shown to inhibit the migration of gastric cancer cells (80) and the overexpression of MMP-7 promoted migration in colorectal cancer cells $(81,82)$, MMP-7 is not only important for cell migration in prostate cancer, but also in various other neoplasias.

MMPs such as MMP-7 may also promote cell growth by fostering the shedding of growth factors or increasing their bioavailability (83). Furthermore, MMPs affect apoptosis, angiogenesis and immune surveillance $(84,85)$. While invasion or angiogenesis is more important during later cancer stages, growth and survival effects of MMP-7 may contribute to the development of hyperplasia and neoplasia at the onset of prostate cell transformation. Thus, MMP-7 may be one target gene that is critical for the reported development of prostatic intraepithelial neoplasia upon ETV1 overexpression $(28,32)$.

In conclusion, our data strongly argue that the upregulation of MMP-7 contributes to the oncogenic phenotype of ETV1 in the prostate. Since dysregulated ETV1 is also implicated in skin, breast and gastrointestinal stromal tumors $(33,86,87)$, our results may not be limited to prostate cancer. As such, inhibiting MMP-7 enzymatic activity using small-molecule drugs may be useful in the treatment of various ETV1-overexpressing tumors.

\section{Acknowledgements}

We thank Dr Eric Howard for providing human MMP-7 cDNA. This study was supported by a grant to R.J. from the National Cancer Institute (R01 CA154745). The content is solely the responsibility of the authors and does not necessarily represent the official views of the National Cancer Institute or the National Institutes of Health. S.A. was supported by the Summer Undergraduate Research Experience Program at the University of Oklahoma Health Sciences Center.

\section{References}

1. Brown TA and McKnight SL: Specificities of protein-protein and protein-DNA interaction of GABP alpha and two newly defined ets-related proteins. Genes Dev 6: 2502-2512, 1992.

2. Coutte L, Monte D, Imai K, Pouilly L, Dewitte F, Vidaud M, Adamski J, Baert JL and de Launoit Y: Characterization of the human and mouse ETV1/ER81 transcription factor genes: role of the two alternatively spliced isoforms in the human. Oncogene 18: 6278-6286, 1999.

3. Sharrocks AD: The ETS-domain transcription factor family. Nat Rev Mol Cell Biol 2: 827-837, 2001.

4. Hollenhorst PC, McIntosh LP and Graves BJ: Genomic and biochemical insights into the specificity of ETS transcription factors. Annu Rev Biochem 80: 437-471, 2011.

5. Oh S, Shin S and Janknecht R: ETV1, 4 and 5: An oncogenic subfamily of ETS transcription factors. Biochim Biophys Acta 1826: 1-12, 2012.

6. Jeon IS, Davis JN, Braun BS, Sublett JE, Roussel MF, Denny CT and Shapiro DN: A variant Ewing's sarcoma translocation $(7 ; 22)$ fuses the EWS gene to the ETS gene ETV1. Oncogene 10: 1229-1234, 1995.

7. Monte D, Coutte L, Baert JL, Angeli I, Stehelin D and de Launoit Y: Molecular characterization of the ets-related human transcription factor ER81. Oncogene 11: 771-779, 1995.

8. Chotteau-Lelievre A, Desbiens X, Pelczar H, Defossez PA and de Launoit Y: Differential expression patterns of the PEA3 group transcription factors through murine embryonic development. Oncogene 15: 937-952, 1997.

9. Chotteau-Lelievre A, Dolle P, Peronne V, Coutte L, de Launoit Y and Desbiens X: Expression patterns of the Ets transcription factors from the PEA3 group during early stages of mouse development. Mech Dev 108: 191-195, 2001.

10. Arber S, Ladle DR, Lin JH, Frank E and Jessell TM: ETS gene Er81 controls the formation of functional connections between group Ia sensory afferents and motor neurons. Cell 101: 485-498, 2000.

11. Kucera J, Cooney W, Que A, Szeder V, Stancz-Szeder H and Walro J: Formation of supernumerary muscle spindles at the expense of Golgi tendon organs in ER81-deficient mice. Dev Dyn 223: 389-401, 2002.

12. Janknecht R: Analysis of the ERK-stimulated ETS transcription factor ER81. Mol Cell Biol 16: 1550-1556, 1996.

13. Bosc DG, Goueli BS and Janknecht R: HER2/Neu-mediated activation of the ETS transcription factor ER81 and its target gene MMP-1. Oncogene 20: 6215-6224, 2001.

14. Janknecht R: Cell type-specific inhibition of the ETS transcription factor ER81 by mitogen-activated protein kinase-activated protein kinase 2. J Biol Chem 276: 41856-41861, 2001.

15. Wu J and Janknecht R: Regulation of the ETS transcription factor ER81 by the $90-\mathrm{kDa}$ ribosomal S6 kinase 1 and protein kinase A. J Biol Chem 277: 42669-42679, 2002.

16. Janknecht R: Regulation of the ER81 transcription factor and its coactivators by mitogen- and stress-activated protein kinase 1 (MSK1). Oncogene 22: 746-755, 2003.

17. Papoutsopoulou S and Janknecht R: Phosphorylation of ETS transcription factor ER81 in a complex with its coactivators CREB-binding protein and p300. Mol Cell Biol 20: 7300-7310, 2000.

18. Goel A and Janknecht R: Acetylation-mediated transcriptional activation of the ETS protein ER81 by p300, P/CAF, and HER2/ Neu. Mol Cell Biol 23: 6243-6254, 2003.

19. Janknecht R: The versatile functions of the transcriptional coactivators p300 and CBP and their roles in disease. Histol Histopathol 17: 657-668, 2002.

20. Lee KK and Workman JL: Histone acetyltransferase complexes: one size doesn't fit all. Nat Rev Mol Cell Biol 8: 284-295, 2007.

21. Goel A and Janknecht R: Concerted activation of ETS protein ER81 by 160 coactivators, the acetyltransferase $\mathrm{p} 300$ and the receptor tyrosine kinase HER2/Neu. J Biol Chem 279: 14909-14916, 2004.

22. Font de Mora J and Brown M: AIB1 is a conduit for kinasemediated growth factor signaling to the estrogen receptor. Mol Cell Biol 20: 5041-5047, 2000.

23. Xu J, Wu RC and O'Malley BW: Normal and cancer-related functions of the p160 steroid receptor co-activator (SRC) family. Nat Rev Cancer 9: 615-630, 2009.

24. Janknecht R: EWS-ETS oncoproteins: the linchpins of Ewing tumors. Gene 363: 1-14, 2005.

25. Toomey EC, Schiffman JD and Lessnick SL: Recent advances in the molecular pathogenesis of Ewing's sarcoma. Oncogene 29: 4504-4516, 2010. 
26. Rossow KL and Janknecht R: The Ewing's sarcoma gene product functions as a transcriptional activator. Cancer Res 61: 2690-2695, 2001.

27. Tomlins SA, Rhodes DR, Perner S, Dhanasekaran SM, Mehra R, Sun XW, Varambally S, Cao X, Tchinda J, Kuefer R, et al: Recurrent fusion of TMPRSS2 and ETS transcription factor genes in prostate cancer. Science 310: 644-648, 2005.

28. Tomlins SA, Laxman B, Dhanasekaran SM, Helgeson BE, Cao X, Morris DS, Menon A, Jing X, Cao Q, Han B, et al: Distinct classes of chromosomal rearrangements create oncogenic ETS gene fusions in prostate cancer. Nature 448: 595-599, 2007.

29. Attard G, Clark J, Ambroisine L, Mills IG, Fisher G, Flohr P, Reid A, Edwards S, Kovacs G, Berney D, et al: Heterogeneity and clinical significance of ETV1 translocations in human prostate cancer. Br J Cancer 99: 314-320, 2008.

30. Hermans KG, van der Korput HA, van Marion R, van de Wijngaart DJ, Ziel-van der Made A, Dits NF, Boormans JL, van der Kwast TH, van Dekken H, Bangma CH, et al: Truncated ETV1, fused to novel tissue-specific genes, and full-length ETV1 in prostate cancer. Cancer Res 68: 7541-7549, 2008.

31. Clark JP and Cooper CS: ETS gene fusions in prostate cancer. Nat Rev Urol 6: 429-439, 2009.

32. Shin S, Kim TD, Jin F, van Deursen JM, Dehm SM, Tindall DJ, Grande JP, Munz JM, Vasmatzis G and Janknecht R: Induction of prostatic intraepithelial neoplasia and modulation of androgen receptor by ETS variant 1/ETS-related protein 81 . Cancer Res 69: 8102-8110, 2009.

33. Jane-Valbuena J, Widlund HR, Perner S, Johnson LA, Dibner AC, Lin WM, Baker AC, Nazarian RM, Vijayendran KG, Sellers WR, et al: An oncogenic role for ETV1 in melanoma. Cancer Res 70: 2075-2084, 2010.

34. Goueli BS and Janknecht R: Upregulation of the catalytic telomerase subunit by the transcription factor ER81 and oncogenic HER2/Neu, Ras, or Raf. Mol Cell Biol 24: 25-35, 2004.

35. Hiyama E and Hiyama K: Telomerase as tumor marker. Cancer Lett 194: 221-233, 2003.

36. Janknecht R: On the road to immortality: hTERT upregulation in cancer cells. FEBS Lett 564: 9-13, 2004.

37. Bosc DG and Janknecht R: Regulation of HER2/Neu promoter activity by the ETS transcription factor, ER81. J Cell Biochem 86: 174-183, 2002

38. Signoretti S, Montironi R, Manola J, Altimari A, Tam C, Bubley G, Balk S, Thomas G, Kaplan I, Hlatky L, et al: Her-2-neu expression and progression toward androgen independence in human prostate cancer. J Natl Cancer Inst 92: 1918-1925, 2000.

39. Osman I, Mikhail M, Shuch B, Clute M, Cheli CD, Ghani F, Thiel RP and Taneja SS: Serum levels of shed Her2/neu protein in men with prostate cancer correlate with disease progression. J Urol 174: 2174-2177, 2005.

40. Nishio Y, Yamada Y, Kokubo H, Nakamura K, Aoki S, Taki T, Honda N, Nakagawa A, Saga S and Hara K: Prognostic significance of immunohistochemical expression of the HER-2/neu oncoprotein in bone metastatic prostate cancer. Urology 68: 110-115, 2006.

41. Dowdy SC, Mariani A and Janknecht R: HER2/Neu- and TAK1mediated up-regulation of the transforming growth factor beta inhibitor Smad7 via the ETS protein ER81. J Biol Chem 278: 44377-44384, 2003.

42. Massague J: TGFbeta in cancer. Cell 134: 215-230, 2008

43. Yan X and Chen YG: Smad7: not only a regulator, but also a crosstalk mediator of TGF-beta signalling. Biochem J 434: 1-10, 2011.

44. De Haro L and Janknecht R: Functional analysis of the transcription factor ER71 and its activation of the matrix metalloproteinase-1 promoter. Nucleic Acids Res 30: 2972-2979, 2002.

45. De Haro L and Janknecht R: Cloning of the murine ER71 gene (Etsrp71) and initial characterization of its promoter. Genomics 85: 493-502, 2005

46. Goueli BS and Janknecht R: Regulation of telomerase reverse transcriptase gene activity by upstream stimulatory factor. Oncogene 22: 8042-8047, 2003.

47. Shin S and Janknecht R: Concerted activation of the Mdm2 promoter by p72 RNA helicase and the coactivators p300 and P/CAF. J Cell Biochem 101: 1252-1265, 2007.

48. Kim TD, Oh S, Shin S and Janknecht R: Regulation of tumor suppressor p53 and HCT116 cell physiology by histone demethylase JMJD2D/KDM4D. PLoS One 7: e34618, 2012.

49. Kim TD, Shin S and Janknecht R: Repression of Smad3 activity by histone demethylase SMCX/JARID1C. Biochem Biophys Res Commun 366: 563-567, 2008.

50. Rossow KL and Janknecht R: Synergism between p68 RNA helicase and the transcriptional coactivators CBP and p300. Oncogene 22: 151-156, 2003.
51. Ben-Levy R, Paterson HF, Marshall CJ and Yarden Y: A single autophosphorylation site confers oncogenicity to the Neu/ErbB-2 receptor and enables coupling to the MAP kinase pathway. EMBO J 13: 3302-3311, 1994

52. Knebel J, De Haro L and Janknecht R: Repression of transcription by TSGA/Jmjd1a, a novel interaction partner of the ETS protein ER71. J Cell Biochem 99: 319-329, 2006.

53. Mooney SM, Goel A, D'Assoro AB, Salisbury JL and Janknecht R: Pleiotropic effects of p300-mediated acetylation on p68 and p72 RNA helicase. J Biol Chem 285: 30443-30452, 2010.

54. Kim J, Shin S, Subramaniam M, Bruinsma E, Kim TD, Hawse JR, Spelsberg TC and Janknecht R: Histone demethylase JARID1B/ KDM5B is a corepressor of TIEG1/KLF10. Biochem Biophys Res Commun 401: 412-416, 2010.

55. Shin S and Janknecht R: Activation of androgen receptor by histone demethylases JMJD2A and JMJD2D. Biochem Biophys Res Commun 359: 742-746, 2007.

56. Mooney SM, Grande JP, Salisbury JL and Janknecht R: Sumoylation of p68 and p72 RNA helicases affects protein stability and transactivation potential. Biochemistry 49: 1-10, 2010.

57. Shin S and Janknecht R: Diversity within the JMJD2 histone demethylase family. Biochem Biophys Res Commun 353: 973-977, 2007.

58. Shin S, Bosc DG, Ingle JN, Spelsberg TC and Janknecht R: Rcl is a novel ETV1/ER81 target gene upregulated in breast tumors. J Cell Biochem 105: 866-874, 2008.

59. Shin S, Rossow KL, Grande JP and Janknecht R: Involvement of RNA helicases p68 and p72 in colon cancer. Cancer Res 67: 7572-7578, 2007.

60. Oh S and Janknecht R: Histone demethylase JMJD5 is essential for embryonic development. Biochem Biophys Res Commun 420: 61-65, 2012 .

61. Kim TD, Shin S, Berry WL, Oh S and Janknecht R: The JMJD2A demethylase regulates apoptosis and proliferation in colon cancer cells. J Cell Biochem 113: 1368-1376, 2012.

62. Ozaki I, Mizuta T, Zhao G, Yotsumoto H, Hara T, Kajihara S, Hisatomi A, Sakai T and Yamamoto K: Involvement of the Ets-1 gene in overexpression of matrilysin in human hepatocellular carcinoma. Cancer Res 60: 6519-6525, 2000.

63. Crawford HC, Fingleton B, Gustavson MD, Kurpios N, Wagenaar RA, Hassell JA and Matrisian LM: The PEA3 subfamily of Ets transcription factors synergizes with beta-catenin-LEF-1 to activate matrilysin transcription in intestinal tumors. Mol Cell Biol 21: 1370-1383, 2001.

64. Wei GH, Badis G, Berger MF, Kivioja T, Palin K, Enge M, Bonke M, Jolma A, Varjosalo M, Gehrke AR, et al: Genomewide analysis of ETS-family DNA-binding in vitro and in vivo. EMBO J 29: 2147-2160, 2010.

65. Janknecht R, Monte D, Baert JL and de Launoit Y: The ETS-related transcription factor ERM is a nuclear target of signaling cascades involving MAPK and PKA. Oncogene 13: 1745-1754, 1996.

66. Holbro T, Civenni G and Hynes NE: The ErbB receptors and their role in cancer progression. Exp Cell Res 284: 99-110, 2003.

67. Cai C, Hsieh CL, Omwancha J, Zheng Z, Chen SY, Baert JL and Shemshedini L: ETV1 is a novel androgen receptor-regulated gene that mediates prostate cancer cell invasion. Mol Endocrinol 21: 1835-1846, 2007.

68. Kumar-Sinha C, Tomlins SA and Chinnaiyan AM: Recurrent gene fusions in prostate cancer. Nat Rev Cancer 8: 497-511, 2008.

69. Yu YP, Landsittel D, Jing L, Nelson J, Ren B, Liu L, McDonald C, Thomas R, Dhir R, Finkelstein S, et al: Gene expression alterations in prostate cancer predicting tumor aggression and preceding development of malignancy. J Clin Oncol 22: 2790-2799, 2004.

70. Pajouh MS, Nagle RB, Breathnach R, Finch JS, Brawer MK and Bowden GT: Expression of metalloproteinase genes in human prostate cancer. J Cancer Res Clin Oncol 117: 144-150, 1991.

71. Hashimoto K, Kihira Y, Matuo Y and Usui T: Expression of matrix metalloproteinase-7 and tissue inhibitor of metalloproteinase-1 in human prostate. J Urol 160: 1872-1876, 1998.

72. Ouyang XS, Wang X, Lee DT, Tsao SW and Wong YC: Up-regulation of TRPM-2, MMP-7 and ID-1 during sex hormoneinduced prostate carcinogenesis in the Noble rat. Carcinogenesis 22: 965-973, 2001

73. Asamoto M, Hokaiwado N, Cho YM, Takahashi S, Ikeda Y, Imaida $\mathrm{K}$ and Shirai T: Prostate carcinomas developing in transgenic rats with SV40 T antigen expression under probasin promoter control are strictly androgen dependent. Cancer Res 61: 4693-4700, 2001. 
74. Szarvas T, Becker M, Vom Dorp F, Meschede J, Scherag A Bankfalvi A, Reis H, Schmid KW, Romics I, Rubben H and Ergun S: Elevated serum matrix metalloproteinase 7 levels predict poor prognosis after radical prostatectomy. Int J Cancer 128: 1486-1492, 2011.

75. Wilson CL, Heppner KJ, Labosky PA, Hogan BL and Matrisian LM: Intestinal tumorigenesis is suppressed in mice lacking the metalloproteinase matrilysin. Proc Natl Acad Sci USA 94: 1402-1407, 1997.

76. Rudolph-Owen LA, Chan R, Muller WJ and Matrisian LM: The matrix metalloproteinase matrilysin influences early-stage mammary tumorigenesis. Cancer Res 58: 5500-5506, 1998.

77. Crawford HC, Scoggins CR, Washington MK, Matrisian LM and Leach SD: Matrix metalloproteinase-7 is expressed by pancreatic cancer precursors and regulates acinar-to-ductal metaplasia in exocrine pancreas. J Clin Invest 109: 1437-1444, 2002.

78. Hollenhorst PC, Ferris MW, Hull MA, Chae H, Kim S and Graves BJ: Oncogenic ETS proteins mimic activated RAS/ MAPK signaling in prostate cells. Genes Dev 25: 2147-2157, 2011.

79. Powell WC, Knox JD, Navre M, Grogan TM, Kittelson J, Nagle RB and Bowden GT: Expression of the metalloproteinase matrilysin in DU-145 cells increases their invasive potential in severe combined immunodeficient mice. Cancer Res 53: 417-422, 1993.

80. Wroblewski LE, Noble PJ, Pagliocca A, Pritchard DM, Hart CA, Campbell F, Dodson AR, Dockray GJ and Varro A: Stimulation of MMP-7 (matrilysin) by Helicobacter pylori in human gastric epithelial cells: role in epithelial cell migration. J Cell Sci 116: 3017-3026, 2003.
81. Remy L, Trespeuch C, Bachy S, Scoazec JY and Rousselle P: Matrilysin 1 influences colon carcinoma cell migration by cleavage of the laminin-5 beta3 chain. Cancer Res 66: 1122811237,2006

82. Lee SK, Han YM, Yun J, Lee CW, Shin DS, Ha YR, Kim J, Koh JS, Hong SH, Han DC and Kwon BM: Phosphatase of regenerating liver-3 promotes migration and invasion by upregulating matrix metalloproteinases-7 in human colorectal cancer cells. Int J Cancer 131: E190-E203, 2012.

83. Ii M, Yamamoto H, Adachi Y, Maruyama Y and Shinomura Y: Role of matrix metalloproteinase-7 (matrilysin) in human cancer invasion, apoptosis, growth, and angiogenesis. Exp Biol Med (Maywood) 231: 20-27, 2006.

84. Egeblad M and Werb Z: New functions for the matrix metalloproteinases in cancer progression. Nat Rev Cancer 2: 161-174, 2002.

85. Deryugina EI and Quigley JP: Matrix metalloproteinases and tumor metastasis. Cancer Metastasis Rev 25: 9-34, 2006.

86. Wang Y, Wang L, Chen Y, Li L, Yang X, Li B, Song S, Yang L, Hao Y and Yang J: ER81 expression in breast cancers and hyperplasia. Pathology Res Int 2011: 980513, 2011.

87. Chi P, Chen Y, Zhang L, Guo X, Wongvipat J, Shamu T, Fletcher JA, Dewell S, Maki RG, Zheng D, et al: ETV1 is a lineage survival factor that cooperates with KIT in gastrointestinal stromal tumours. Nature 467: 849-853, 2010. 